\title{
Bæklunarskurðlækningar í úlfakreppu
}

Undirritaður kom til starfa á bæklunarskurðdeild Landspítala 1995, eða fyrir nær aldarfjórðungi. Ýmsar breytingar hafa orðið á peim tíma og pær kannski stærstar sem fólu í sér sameiningu sjúkrahúsanna priggja í Reykjavík. Var sú sameining framkvæmd í nafni samlegðaráhrifa og sparnaðar. Ekki hefur pað pó nægt og hefur krafan um sparnað, niðurskurð og jafnvel ráðningarstopp nær samfellt verið til staðar pennan aldarfjórðung. Fjármagni hefur verið veitt í eitt og eitt verkefni svona rétt til að halda höfði og umræðan og óendanlegur undirbúningur nýja pjóðarsjúkrahússins hefur gleypt tíma og fjármagn. Um eiginlega uppbyggingu hefur varla verið аð ræða og paðan af síður hefur verið unnið eftir nokkurri heildstæðri áætlun pótt pjóðhagslegir vísar um mannfjöldapróun, breytingar á samsetningu pjóðarinnar, komur ferðamanna og fleira liggi fyrir á hverju ári. Afleiðing pessa er nú öllum að verða ljós.

Bæklunarskurðdeild Landspítala ber alls pessa merki. Um stóra og punga sérgrein er að ræða og til að breyta par einhverju svo heitið geti parf mikið til. Á grunni takmarkaðs húsnæðis, skertrar eiginlegrar starfsemi vegna skorts á legurými sem að miklu leyti hefur verið upptekið af öldruðum sem ekki komast heim eftir brotameðferð, hefur deildin lengi verið rekin á rauðu. Á meðan nýting á hvoru tveggja, legurými og úthlutuðu skurðstofurými, hefur verið yfir 100\% hefur skurðaðgerðum fjölgað frá aldamótum úr tæplega 2500 í 3000 á ári. Legutími legudeilda hefur haldist svipaður pótt aðgerðir sem krefjast stuttrar legu hafi að mestu verið fluttar yfir á dagdeild. Göngudeildarkomum hefur fjölgað um fjórðung. En prátt fyrir petta hefur biðlisti eftir aðgerðum eingöngu lengst óverulega. Á sama tíma hefur fjöldi lækna haldist að heita má óbreyttur.

Er petta að sjálfsögðu frábært. Í pessu felst pó raunveruleg og sannast sagna yfirvofandi hætta.
Starfsfólk deildarinnar hefur áorkað pessu með pví að leggja á sig á köflum ómanneskjulegt álag. Eru sprungur farnar að myndast í glansmyndina og má líklegt telja að ef engin breyting verður á næstu 1-2 árum pá hreinlega gefist læknar og annað starfsfólk upp með tilheyrandi afleiðingum og niðurfellingu á sjálfsagðri pjónustu við slasaða og pá sem til dæmis eiga við slitgigtarsjúkdóma að stríða og purfa á liðskiptaaðgerðum að halda. Sem tímabundna lausn má hugsa sér að láta pessa pjónustu fara fram annars staðar, hættan með pví er pó sú að með pví sé sérgreinin bæklunarskurðlækningar holuð að innan og ekki ólíklegt að með fylgi starfsfólk sem sér sig betur sett í vakta- og streitulausu umhverfi einkastofunnar. Er pá verr af stað farið en heima setið.

Má pannig segja að bæklunarskurðlækningar á Landspítala séu á einhvern hátt í sjálfheldu eigin stærðar og endalausra sparnaðarkrafna par sem erfitt er að breyta starfseminni án kostnaðar og með nokkrum tilfæringum. Á pað til dæmis við ef flytja á og koma fyrir göngudeildarstarfsemi sérgreinarinnar á viðunandi stað. Án breytinga annars verður pó að segja að fyrir liggi pegjandi sampykki fyrir 1000 manna biðlista og um leið helst prýstingurinn á að bæklunaraðgerðir verði í auknum mæli fluttar af sjúkrahúsinu.

Að pessu sögðu verður pó að ítreka að með litlum breytingum á legudeildum (til dæmis eyrnamerkja gerviliðaaðgerðum 1-2 rúm til viðbótar), fullri nýtingu á skurðstofum sem pegar eru til og tilsvarandi fjölgun starfsmanna er hægt að vinna pennan biðlista tiltölulega vel niður. Er pá hægt að sinna til dæmis gerviliðaaðgerðum á mannsæmandi hátt og halda peim par sem pær eiga heima, pað er á Landspítala eða öðru sérgreinasjúkrahúsi.

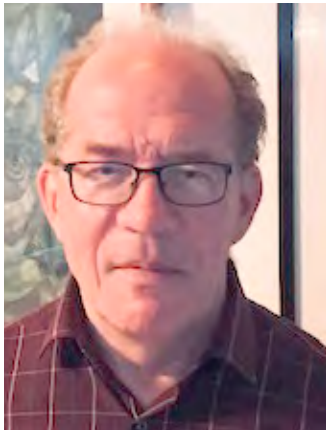

\section{Yngvi Ólafsson}

yfirlæknir bæklunarskurðdeildar Landspítala

Yngviola@gmail.com

\section{Orthopaedic surgery in Iceland on crossroads}

Yngvi Ólafsson MD PhD, head of Orthopaedic surgery department, Landspitali University Hospital

doi.org/10.17992//bl.2019.06.233 